\title{
Reflections on Association of Production, Education and Research in the Context of Application-oriented Universities
}

\author{
Peng Xing \\ Jingdezhen ceramic University \\ Qiushi Road Xianghu village in XianghuTown, Fuliang County,Jingdezhen city, Jiangxi Province, \\ China \\ kavana1011@126.com
}

Keywords: Applied talents; Industry universities; Association

\begin{abstract}
Applied talents are an important measure of national personnel training strategy adjustment, and are also the inevitable choices of education in the economic and social development. Under the new situation, this paper advocates the objective necessity and practical value and significance of association of Production, Education and Research carried out in application-oriented universities, and how to cultivate applied talents through the association in the new period strategy.

The "national long-term education reform and development plan(2010-2020)"clearly points out: "to optimize the structure of higher education, the optimization of specialty, type, level structure, and promote interdisciplinary integration; to focus on expanding the application type, compound type, the scale of training skilled personnel". This is the historical background of the economic transformation of higher education personnel training strategy, but also the national level for the first time the application of personnel training to write a formal document. The international standard classification of education will be divided into three categories: a comprehensive research university, the development of natural science, social sciences and humanities research talent; the application of multidisciplinary professional or single universities or colleges, cultivate a solid theoretical foundation of the different levels of the senior specialized personnel and management personnel, such as lawyers, teachers, engineers, physicians and other "teacher" talents; vocational and technical colleges and universities train in production, management, service in the first line of the specific work of technical personnel[1]. The second kind of university mainly refers to the application-oriented colleges which specialize in training applied talents. At present, China's economic development is changing from dependence on resources, labor force to rely on innovation, talent transformation, economic and social development, which is crying for a large number of high-quality applied talents who graduate from the university. It has become an urgent problem that how to cultivate high quality applied talents in application-oriented universities, and the construction of production, education and research will become an important part of the reform of higher education.
\end{abstract}

\section{The Objective Necessity of the Development of Association of Production Education and Research}

The Emergence and Development of Association of Production, Education and Research, Which is Determined by the Needs of the Transformation and Development of Higher Education.

China is in a critical period of economic transformation, especially the 18th National Congress of CPC puts forward the goals of "new industrialization, informationization, urbanization and agricultural modernization. And the new four modernizations require the transformation of the path of industrialization, that is to say, the transition from traditional industrialization to new industrialization. At this point, how to adapt to the need of socialist economic construction, has become the key issue of deepening the reform of education. Hence, we should break the manacles of the traditional system, and carry out reform in the stage of practical training. On the other hand, it is urgent for application-oriented undergraduate universities to cultivate application-oriented qualified personnel to meet the need of social development. At the same time, it would be necessary 
to take the path of association of Production, Education and Research so as to make full use of the advantages of intelligence, technology, disciplines, information and sensitivity, serve the society and make ourselves develop.

The Transformation of Scientific Research Achievements into Practical Productive Forces.

Science and technology serve for production, which are the requirements of the scientific research department. If researchers not only know little about the actual production and the market demand, but also just rely on studying in the laboratory and selecting items from books, it would be difficult to meet the needs of social and economic development, and enterprises are hard to adopt as well. These days some achievements in scientific research are shelved for lack of contact with the actual production. Therefore, in order to make the scientific achievements of scientific research department and the actual production in full accord, meet the needs of economic construction and social development and make the science of the potential productivity into real productivity, it is bound for our government to take the path of education, scientific research and production.

The urgent requirement of enterprise development. At present, the level of technology and equipment and the quality of labor force is not high enough, which seriously affects the economic efficiency and development of enterprises. Today, with the development of science and technology, in order to survive, enterprises have to adopt scientific technology and advanced process equipment, improve the quality of workers, reduce the cost of products and continue to produce new products to meet the needs of people's material and cultural life. It also requires enterprises to strengthen the joint with colleges and universities that provide technical support and talented personnel for them.

\section{The Practical Significance of Promoting the Development of Association of Production, Education and Research}

\section{Conducive to Promoting the Reform of the Management System of Colleges and Universities.}

The existing higher education system in China is not perfect in respect to the self-isolation and compartmentalization, which leads to students out of society and production, and also can not meet the need of socialist economic construction and play a direct role in promoting the development of social production. At the same time, social investment enthusiasm is not high. Therefore, through the cooperation of universities and enterprises, they will play their respective advantages to obtain the best combination in a wide range. What's more, they also will pay more attention to the school efficiency to cultivate high quality talents and promote the reform of higher education management system by intellectual investment and the use of talents together.

\section{Conducive to the Growth and Improvement of Teachers.}

In twenty-first century, the most important competition is the competition of talents. By the formation of association of Production, Education and Research can increase the opportunity of contracting with practice for teachers who would have a better understanding of the various aspects of the community's need for talent specifications, so as to meet the need of the community to carry out professional reform, curriculum reform and teaching materials reform. In addition, it urges teachers to incorporate the latest knowledge and information in which they have come into contact with the teaching materials and handouts in the process of solving the problems of technology and production. So their teaching can not only track the world's advanced level of scientific and technological development, but also the theory with practice, which enrich the teaching content. Besides, students can also learn the latest developments in their professional. Therefore, the teaching effect and quality can be improved, and the phenomenon that separating of existing theory and practice, aging of knowledge and obsolete teaching content, which are improved as well.

\section{Conducive to the cultivation of talents.}

At present, the main problems existing in the quality and capacity of college graduates are considering personal benefits, lacking of the sense of responsibility and the ability of cooperation and communication with others, unreasonable professional knowledge structure[2]. These problems are closely related to the problems of universities and the teaching team itself. So colleges and universities should make full use of the advantages of association of Production, Education and Research and provide students with a stable practice base, which make their social practice 
activities ensured and increase the opportunities of contacting with practice and understanding society. Through social practice, on the one hand ,it not only is beneficial for college students to correct their political orientation and strengthen their ideological and political education, but can make students learn to enhance their senses of social responsibility and dedication and improve the enthusiasm and awareness of teaching. On the other hand, it is also helpful for students to overcome the shortcomings of putting emphasis on theory and bad tendency of the reality, and enhance their ability of analyzing and solving problems, so as to deliver qualified talents for our country.

\section{The Countermeasures of Accelerating the Development of Association of Production Education and Research}

\section{Accelerate the Pace of Resource Allocation and System Reform.}

Nowadays, there are still many problems in the allocation of scientific and technological resources, which place obstacles to the technological innovation of association of Production, Education and Research. Scarce resources not only can not meet the need of innovation, but also make it difficult to get the full effect of the alliance and the stable operation of the alliance has been tested. In terms of the system, the government has too much control over the university, which results in the phenomenon of university administration intensified, making university teachers inactive and lacking of its own characteristics. Therefore, the central government has given the autonomy of running schools and the administration of colleges and universities in the reform of educational system that makes colleges and universities truly become a relatively independent entity on the basis of the implementation of national policies, decrees and plans. In addition, the government's macro management functions of colleges and universities should be changed from direct to indirect management and transfer more power to colleges and universities, which let them independent, professional, academic.

\section{Formulate Policies and Regulations on the Development of Association of Production Education and Research.}

At present, both the central and local governments have fully recognized the importance of the development of association of Production, Education and Research, and stress the need to promote its development. So far, China has promulgated the "national long-term education reform and development plan (2010-2020)" and the "outline of the national long-term talent development plan (2010-2020)" that reflect the will of the government and with the support of the plan of excellent engineers and collaborative innovation 2011 plan, which help to promote the communication and cooperation between universities and society. However, there are no specific regulations in the aspect of association of Production, Education and Research. In the process of university combination, university leaders often feel desperate and can not develop a specific situation to adapt to the implementation of the university. Therefore, it is necessary to formulate policies and regulations on the development of association of Production, Education and Research, and to strengthen the guidance, supervision and management of the couplet in the form of law.

Colleges and Universities should Deepen the Understanding of the Importance of Establishing Association of Production, Education and Research.

University leaders and departments should strengthen management awareness and establish association of Production, Education, and Research to overcome the thought and practice of looking down upon association .Moreover, they also should carry out horizontal joint instructions and regulations that are ordered by the government, and formulate the implementation and management methods of the university on this basis to promote the development of education, scientific research and production association into the school schedule and be guaranteed on human, material and financial resources.

Apart from these, they ought to constantly sum up experience, study new problems and make the necessary coordination on the major projects. Nevertheless, due to the impact of the traditional prejudice, such as valuing theory over practice, heavy academic works and thesis writing, ignoring the practical problem, many universities don't pay enough attention to the development of technology and lack respect for the achievements of technology development. What's worse, some 
associations become a mere formality after the establishment, which is the result that the university can not continue to provide new technical support and research achievements. In other words, after the establishment of the association, the university should not only emphasize the basic research, but also pay attention to the applied research and keep the development potential, which make for the consolidation and sustainable development of the association.

\section{Improve the Coordination Mechanism of the Internal Interest Distribution.}

The mechanism of profit distribution is the key problem of the stability of association of Production, Education, and Research. However, one of the most important reasons for the current study of the stability of the association is the unfair distribution of interests or not meeting the need of its members [3].There are some contradictions in the joint process between enterprises and universities. For example, they both often do not agree on the ownership of property rights on the issue of joint research institutions. Besides, in terms of transfer fees and income distribution, universities often require a one-time payment or in proportion to sales while enterprises insist on extracting from profit year by year. However, these contradictions not only affect the formation of the association, but also affect its consolidation and development. Therefore, it is necessary for enterprises to establish and improve the basic principles of equality and mutual benefit in the process of internal benefit distribution and constantly adjust the distribution of benefits, so as to achieve the rational allocation of the interests of the state. It is also vital to deal with the relationship between the immediate interests and long-term interests at the same time.

\section{Conclusion}

To sum up, the integration of production, education and research is the source of strength for the development of application-oriented talents and promoting the development of the career in Application-oriented Universities. University-enterprise cooperation and industry cooperation are the inevitable way of applied talents training. Only by vigorously promoting the integration and combination of production, education and research in Application-oriented Universities, can we improve the level of scientific research and the ability to serve the society, build a high level of applied teachers, and make the university and the industry develop in harmony, which lay the foundation for the cooperation between enterprises and universities.

\section{References}

[1] Pan Maoyuan, Wu Mei: Classification and Orientation of Higher Education [J]. Fudan Education Forum.2003 (1): P31.

[2] Hao Keming.Discussion on the Cultivation of Innovative Talents with High Quality [J]. Education Research, 2007, (6): P12.

[3] Jiang Fuxin et . Research on the Forming Path and Stability of Association of Production, Education and Research [J] Shanghai Economic Research.2014.8.P63 